\title{
ДИСЦИПЛІНАРНІ ФОРМИ ФУНКЦІОНУВАННЯ ТЕОРІЇ ТА ПРАКТИКИ В НАУЦІ
}

\begin{abstract}
C.M. Зуєв
Проблема взаємодії «теоретичного» $\mathrm{i}$ «практичного» $є$ широко дослідженою у філософській літературі. Проте їі актуальність не зменшується, а навпаки зростає у зв'язку з постійним винайденням нових форм опосередкування теорії та практики. Ми пропонуємо поглянути на проектування як на нову форму теоретико-практичного синтезу. Проектування і конструювання, які традиційно розглядалися як специфічні методи технічних наук, сьогодні проникли у всі галузі наукового пізнання і здобули статус загальнонаукових методів. Для того, щоб розкрити евристичні можливості проектування і зрозуміти його гносеологічний статус, звернемося до матеріалу технікознавчих і природничих наук, а також дослідимо проблему співвідношення природознавства і технікознавства.

Виявлення специфіки технічних наук здійснюється, як правило, наступним чином: технічні науки порівнюються 3 природничими науками і одночасно розглядається співвідношення фундаментальних і прикладних досліджень. При цьому виділяється три основні позиції:

1) технічні науки ототожнюються з прикладним природознавством;

2) природничі і технічні науки розглядаються як рівноправні дисципліни;

3) в технічних науках виділяються як фундаментальні так і прикладні дослідження.

Ми притримуємося тієї точки зору, згідно якої технічні і природничі науки повинні розглядатися як рівноправні наукові дисципліни.
\end{abstract}

Актуальні проблеми духовності

(Відп. ред.: Я.В. Шрамко)

Кривий Ріг (2007), 236-244 
Кожна технічна наука - це окрема, відносно автономна дисципліна, яка має ряд особливостей. Технічні науки - частина науки, $\mathrm{i}$ хоч вони не повинні далеко відриватися від технічної практики, не співпадають 3 нею. Технічна наука обслуговує техніку, але є перш за все наукою, тобто діяльністю, направленою на отримання об'єктивного знання 3 можливістю його соціальної трансляції [17].

В результаті науково-технічних революцій, що відбулися в ядерній енергетиці, галузі космічних досліджень, кібернетиці, нанотехнологіях та інших галузях, технічне перетворення буття набуло планетарного масштабу, що вже можна позначити як виникнення техносфери. Це явище має той же статус, що й оформлення ноосфери. Усвідомлення глобальності наслідків людської діяльності відбувається на початку $\mathrm{XX}$ ст. А тому не дивно, що поняття техносфери та ноосфери виникають майже одночасно. В 1934 р. Н.А.Бердяєв висловив думку, що «головна космічна сила, яка зараз діє та перетворює землю і людину, дегуманізує і знеособлює їх є ... техніка... Наша епоха перебуває передусім під знаменом техніки і може бути названа технічною епохою» [2, c. 50]. А В.І. Вернадський в 1937 р. на Міжнародному геологічному конгресі говорить: «Ми живемо в епоху, коли людство вперше охопило в бутті планети всю Землю. Біосфера перейшла в новий стан - в ноосферу» $[4$, с. 73$]$.

Ноосфера - це проблема перетворення природи, а техносфера - це перетворення на базі конструювання та проектування буття в його теперішньому та майбутньому вимірах. Наочним чином на передній план світової цивілізації висунулось явище, яке було і раніше, але зараз набуло всесвітнього масштабу: людське буття, тобто реальність в їі олюдненому вияві, стало предметом всеохоплюючого конструювання. Виникло саме поняття не просто реальності як предмету пізнавального споглядання, а проблема конструювання реальності.

Інакше кажучи, реальність стала задаватися у вигляді штучного середовища. Те, що ми звемо реальним, стало, насамперед, штучним. Не буде перебільшенням сказати, що речі так званої першої та другої природи фактично помінялися місцями. «Природа вже не $€$ просто нашим оточенням. Середовище, яке поступово створюється навколо нас, $\epsilon$, передусім, всесвітом Машини. Техніка сама стає середовищем в самому повному смислі цього слова. Техніка оточує нас, ніби кокон, який робить природу (за нашою першою безпосередньою оцінкою) повністю покірною, вторинною, малозначущою. Єдине, що має значення це Техніка. Природа стала демонтованою науками і технікою: техніка створила цілісне середовище існування, в якому людина живе, відчу- 
ває, думає, отримує досвід» [19, с. 25].

Такі феномени і привели до того, що почали стиратись грані між технічними і природничими науками. Як правило, техніка пов'язувалася 3 поняттям конструювання машин. В сучасних умовах поняття машини набуло програмно-інтелектуального вияву. Машина стала не тільки матеріальною речовою системою, а й феноменом інтелектуальних технологій. Технології стали визначатися вже як евроритми, на відміну від звичайних алгоритмів, які є логічними актами, а не схемами творчості в певних електронно-інформаційних системах. Це дозволило переглянути колишні уявлення про різницю між природними та штучними феноменами.

Основна методологія технічного знання, тобто конструювання та програмування, стали загальним напрямом дослідництва у всіх наукових сферах. Як відомо, раніше прикладом теоретичного технікознавства були дві дисципліни-славнозвісний «сопромат» та теорія електричних ланцюгів. Зараз виник цілий масив технічних теорій, які пов'язані з електронними технологіями. Ми не випадково почали з формування техносфери, адже генералізація технічних засобів у вигляді інформаційних технологій визначило загальнопланетарні системи у статусі самого процесу наукового дослідження, коли через комп'ютерні мережі дослідження однієї лабораторії включається в загальний стан світової науки. Яскравий динамічний приклад взаємодії фізиків-теоретиків через Інтернет в процесі створення теорії суперструн можна знайти в науково-популярній роботі Браяна Гріна [6].

Сама теоретична складова дослідження набула технологічного вигляду. Проблема постала таким чином: будь-яка теоретична схема через програмно-комп'ютерні засоби i, навіть, Інтернет, стає актом, що включений в технологічні системи, тобто виникнення техносфери планети в її електронно-інформаційному вигляді не тільки розмиває різницю між технікою та наукою, а й заповнює колишню прірву між теорією та практикою, між «теоретичним» та «практичним». Тут виникає особлива проблематика, що об'єднує сучасний інтелектуальний ресурс людства, виникає теорія штучного буття (приклад: створення елементарних частинок та трансуранових хімічних елементів). Це новий крок цивілізації, яка стає цивілізацією штучного. Це і актуалізує проблему переходу від теоретичного до практичного і навпаки, та висуває на авансцену наукового дослідження проблему синтезу.

Тут слід підкреслити евристичне передбачення Гегеля, для якого в «Науці логіки» перехід від теоретичного до практичного був не оречевленням ідей, не енергетичним процесом, а трансформацією си- 
стемного матеріалу. Можна сперечатися відносно схоластичного гегелівського викладу цієї ідеї, але сама ідея централізації та генералізації «окремого» в системі «цілого», яка керує описом трансформації «теоретичного» $\mathrm{y}$ «практичне», виявляється евристичною з погляду сучасної електронної епохи. Ми бачимо, що вияв практичної визначеності «теоретичного» в сучасних інформаційно-технологічних системах має інтелектуально-технічний вимір, який $є$ більш важливим, ніж конкретні матеріальні дії. Підтвердженням сказаного і $є$ власне розкриття евристичних можливостей методів конструювання і проектування.

Прикладом однієі з перших технікознавчих теорій є теорія електричних ланцюгів. Застосування на початку 20 -х років XX ст. щойно створеної теорії комплексних чисел в електротехніці дозволило створити схеми заміщення та метод еквівалентного перетворення електричних ланцюгів. Згодом склалися такі процедури теоретичного дослідження, завдяки яким став можливим перехід від структурно-морфологічних зображень різних електротехнічних пристроїв, за допомогою яких аналізується фізична картина процесів, що відбуваються, до зображення цих процесів в електричних схемах заміщення.

Схеми заміщення є абстрактними об'єктами електротехнічної теорії. Вони не претендують на зображення того, що відбувається насправді, це не модель процесу чи явища, а спосіб його представлення в теорії. Такі схеми взагалі спочатку називали фіктивними. Але за ними закріплюються методики і алгоритми обчислень, це своєрідний інструмент для побудови ефективної методики розрахунків. Поступово було напрацьовано набір найчастіше використовуваних, зручних схем заміщення, які відповідають відповідним стандартним задачам в електротехнічній практиці. Зараз немає необхідності кожного разу виводити схеми заміщення, потрібно вміти обгрунтовано обирати потрібні з числа створених раніше [16, с.66].

Інший приклад евристичної ролі методу конструювання знаходимо при вивченні сучасних інформаційних технологій, зокрема програмування. Перші мови програмування мали машинно-орієнтований характер, тобто були жорстко прив'язані до архітектури кожного конкретного комп'ютера. Але вже тоді вдавалося будувати програмні моделі складних об'єктів чи явищ. Комп'ютерне моделювання відкрило шлях до вивчення об'єктів, над якими неможливо проводити експерименти в силу їх унікальності або недоступності. До них відносяться, наприклад, Земля, її атмосфера, біосфера, зоряні системи, соціальні процеси, ядерні та зоряні війни і багато інших.

В 90-х роках минулого століття картина суттєво змінилася. Вина- 
йдення технології об'єктно-орієнтованого проектування (ООП) і створення на її базі нових мов програмування, дало можливість повністю абстрагуватися від апаратної складової ЕОМ і зосередитися на об'єкті, що вивчається. Більш того, сучасне програмування орієнтоване на предметну область. Поява предметної області в ООП $\epsilon$ свідченням переходу програмування в сферу дослідницької діяльності в контексті розвитку його як технічної дисципліни.

Головна одиниця, якою оперує об'єктно-орієнтована мова програмування, як можна судити з назви самої технології, є об'єкт. Об'єкт складається з двох основних частин - властивостей (полів) та методів. Властивості-це певні характеристики об'єкта, які є суттєвими для його моделювання і які виділяють його з поміж інших об'єктів. Методи - це дії, які може виконувати об'єкт. Специфічним видом методів $\epsilon$ подія (event) - це реакція об'єкта на деякий зовнішній подразник. Сукупність однотипних об'єктів є класом. Технологія ООП базується на трьох основних механізмах. Це інкапсуляція (поєднання властивостей і методів в одній структурі-класі), наслідування (можливість створення нових класів на базі існуючих) і поліморфізм (надає можливість об'єкту виконувати одну і ту ж дію по-різному в залежності від конкретних обставин). Саме в наслідуванні і поліморфізмі приховані основні проективні і евристичні можливості об'єктно-орієнтованого підходу. Наслідування неможливе без абстрагування - виділення лише тих властивостей об'єкта, які є суттєвими для його моделювання.

При правильному застосуванні наслідування новий клас (потомок) $\epsilon$ менш абстрактним ніж старий (батьківський), оскільки в ньому крім наслідуваних є нові властивості і методи. Класи, об'єднанні відношенням наслідування, називаються спорідненими. Споріднені класи утворюють ієрархії [3]. В деяких мовах програмування всі класи $є$ спорідненими і наслідуються явно чи опосередковано від одного базового класу. Це з одного боку обмежує програміста і змушує його строго дотримуватися основних правил при створенні власних класів, але при цьому з'являється надзвичайно корисна можливість маніпулювати всіма об'єктами різних класів одночасно.

Ми не випадково так детально зупинилися на технології ООП. Ї̈̈ впровадження надало можливість моделювати існуючі та проектувати і конструювати нові системи будь якої складності.

В термінах об'єктно-орієнтованого проектування система описується не як послідовність подій, а як сукупність об'єктів, кожен з яких має індивідуальні характеристики і систему поведінки. В процесі проектування складність системи можна нарощувати поступово, шляхом 
введення в неї нових об'єктів або ускладненням існуючих. Створені таким чином програмні системи за своєю функціональністю наближаються до реальних, де кожен об'єкт функціонує незалежно від інших, але як складова єдиного цілого.

Розглянемо онтологічний і гносеологічний статус програмних систем. У якій формі вони існують і як співвідносяться з об'єктивною реальністю? До якої форми відносяться знання, здобуті в процесі створення і функціонування програмної системи, теоретичної чи емпіричної?

Програмний світ - це світ штучно створених сутностей, у реальності логічних зв'язків та операційних можливостей яких не можна аж ніяк сумніватись, тому що чим точніше, виразніше цей світ абстракцій, тим більше сценаріїв майбутнього розвитку і варіантів використання підтримує програма. Дієвий характер програмного світу, здатність змінювати реально існуючу функціональність $\epsilon$ підставою для виокремлення цього світу з концептуальних форм фіксації інших проявів особливого типу реальності-від гіперреальності, віртуальної реальності та від кіберпростору як кіберсцени [15, с. 186].

Чи існує програмний світ? У вигляді діаграм, логічних моделей, уніфікованих представлень - безумовно існує. У вигляді створюваних програмною системою функцій та ефекту її поведінки у суспільному контексті- безсумнівно. Проте досі питання про онтологічний статус логічних зв'язків між його поняттями - класами залишається відкритим. Але на відміну від будови наукової теорії знакова природа мовної фіксації цих логічних конструкцій програмного світу не ставить під сумнів існування його складових (абстракцій, ієрархій) поза психічною формою свідомості людини [15, с. 187].

Сучасна наукова методологія стверджує онтологію знання шляхом введення різних рівнів об'єктивації ідеальних конструкцій на зразок «третього світу» К. Поппера. Не менш виразною формою опосередкування матеріального та ідеального виступає програмний світ, що існує у формі операцій, функцій, які забезпечують виконання соціальноорієнтованих дій, відкритих для користувача саме завдяки створеним абстракціям. I що головне, основою цих операцій і функцій, прихованою від користувача, $є$ саме найвищі рівні абстракції та узагальнення. Це й актуалізує питання про реальність існування логічної форми програмного світу.

Як бачимо, програмування, як форма людської діяльності, дуже тісно зближається з проектуванням. Програмна система, так само як i проект, $є$ проміжною, інтегруючою ланкою між теорією і практикою, 
адже вона будується за алгоритмами практики, а функціонує у вигляді теоретичної побудови. Когнітивні і креативні можливості проектування проявляють себе і в мікросвіті, де проект не тільки наближається до теоріï, а й починає з нею конкурувати [11, с. 138].

Альтернативною до квантової хромодинаміки $є$ теорія суперструн, яка намагається сконструювати всі елементарні частинки у вигляді різних мод коливань так званої струни в 11-ти вимірному простоpi. Математичною ідеалізацією струни є деяке математичне рівняння. Змінюючи значення коефіцієнтів цього рівняння, можна отримати характеристики всіх відомих елементарних частинок [6], [7]. Тут, мабуть, доречно згадати Піфагора, який в якості першооснови всіх речей вважав число. Такий підхід $є$ дуже близьким до сучасної методології вивчення фізичної реальності: «зараз фізична реальність не стільки репрезентується, описується, а скоріше конструюється за допомогою ідеальних (частіше математичних) засобів, в тому числі з використанням обчислювального (комп'ютерного) експерименту» [13, с. 266].

Найбільшою проблемою теорії суперструн є їі надлишковість. Існуючі на сьогодні варіанти теорії описують не лише всі відомі елементарні частинки, а й передбачають існування великої кількості нових, частину з яких, у випадку їхнього існування, вже давно б відкрили, застосовуючи сучасні прилади. Для перевірки різних аспектів теорії фізики залучають величезну кількість ресурсів - інтелектуальних, енергетичних, фінансових. На сучасних прискорювачах створюються такі умови для існування частинок і самі елементарні частинки, які у Всесвіті, можливо, взагалі не існують. «Йде процес не тільки побудови все більш абстрактних, загальних і смислоємких теоретичних систем, а й процес актуалізації математичних структур та математичних об'єктів» [13, с. 231].

Проективні функції виявляє і теорія генетичного коду, яка через механізм синтезу білка (за структурою ДНК та трансляцією РНК) розкриває можливості проектування різних фенотипічних властивостей організмів і навіть побудови химерних біологічних утворень. Так само можна характеризувати і теорію синтезу дедуктивних автоматів, що дозволяє проектувати різні кібернетичні системи [11, с. 139]. У зв'язку з цим просто неможливо обійти стороною нанотехнології. Нанотехнології- це вже реальність. Вони відкривають перед нами шлях до маніпулювання матерією на рівні атомів, дають можливість створювати матеріали і механізми будь-якої складності і функціональності. Нанороботи зможуть виконувати будь-яку роботу, керуючись певною програмою, при цьому затрати енергій будуть мінімальними. 3 одного 
боку, нанотехнології, як і велика кількість більш ранніх технологій, можуть знищити людство. 3 іншого - вони дають можливість повністю змінити напрямок людської еволюції. Людина - єдина істота на Землі, яка не пристосовується до зовнішнього середовища, а активно його перетворює, задовольняючи свої потреби. В своїй перетворюючій діяльності ми вже дійшли тієї межі, за якою можливе повне знищення біосфери планети. Нанотехнології дають можливість змінити напрямок цієї діяльності. Можливо людство перестане змінювати природу, а почне змінювати себе [10].

Наведені приклади свідчать про те, що проектування і конструювання, які традиційно розглядалися як специфічні методи технічних наук, сьогодні проникли у всі галузі наукового пізнання і здобули статус загальнонаукових методів. Таким чином, границя між технічними i природничими науками стає менш визначеною. Довгий час фундаментальні дослідження асоціювалися з природничими науками і теоретичною діяльністю, а прикладні дослідження - 3 технічними науками i практичною діяльністю. На сьогодні це вже не відповідає дійсності, адже технічні науки дають можливість здобути фундаментальні знання з основ світобудови; а теоретичні схеми, які б абстрактні вони не були, все частіше актуалізуються, втілюються в наше життя [8]. На цьому шляху може бути прослідковано взаємовплив наукового та інженерного підходів, що виражається і в фундаменталізації технічних наук, і в зміні норм та ідеалів пізнавальної діяльності, і в синтезі інженерних методів та природничонаукових концепцій, отже поглиблюється тенденція до інтеграції суспільних, природничих та технічних наук.

\section{1 Бібліографія}

[1] Баландин P.К. Ноосфера или техносфера // Вопросы философии. -2005. - №6. - С. 107-116.

[2] Бердлев Н.А. Судьба человека в современном мире.-Париж, 1934.

[3] Буч Г. Объектно-ориентированный анализ и проектирование с примерами приложений на $\mathrm{C}++.-$ М.: Изд. Бином, 1999.

[4] Вернадский В.И. Избранные сочинения. Т. 1.- М., 1954.

[5] Гегель Г.В.Ф. Наука логики.-СПб., 1997. 
[6] Грин Б. Элегантная Вселенная. Суперструны, скрытые размерности и поиски окончательной теории.-М.: Едиториал УРСС, 2005 .

[7] Грин М., Шварц Дж., Виттен Э. Теория суперструн: В 2-х т. Т. 1. Введение. - М.: Мир, 1990.

[8] Дротянко Л.Г. Феномен фундаментального і прикладного знання (Постнекласичне дослідження). К.: Вид-во Європ. ун-ту фінансів, інформ. систем, менеджм. і бізнесу, 2000.

[9] Ефременко Д.В. Введение в оценку техники.-М., 2002.

[10] Кишинец B.M. Nano Sapiens или Молчание небес.-M., 2004.

[11] Кримсъкий С.Б. Запити філософських смислів. - К.: ПАРАПАН, 2003.

[12] Кудрин Б.И. Ещё раз о третьей научной картине мира. Материалы к VI научной конференции по философии техники и технетике. Томск: Изд-во Том. ун-та, 2001.

[13] Ратников В.С. Физико-теоретическое моделирование: основания, развитие, рациональность. К.: Наукова думка, 1995.

[14] Розин B.M. Техника и социальность // Вопросы философии. 2005. - № 5. - C. 95-107.

[15] Рубанець O.M. Інформаційне суспільство: когнітивний креатив постнекласичних досліджень. - К.: ПАРАПАН, 2006.

[16] Симоненко О.Д. Методологические особенности теоретического технического Знания // Вопросы философии. - 1987. - № 5. C. 63-70.

[17] Степин B.C., Горохов В.Г., Розов М.А. Философия науки и техники.- М.: Гардарики, 1996.

[18] Хант Ө., Томас Д. Программист-прагматик. Путь от подмастерья к мастеру. - М.: Лори, 2004.

[19] Эллюль Ж. Другая революция // Новая технократическая волна на Западе. - М.: Прогресс, 1986. 